\title{
EVALUASI PENERAPAN SISTEM AKUNTANSI PENERIMAAN DAN PENGELUARAN KAS PADA PT. CIPUTRA INTERNASIONAL CABANG MANADO
}

\author{
Indra Ningsih Katili ${ }^{1}$, Jenny Morasa ${ }^{2}$, Novi S. Budiarso ${ }^{3}$ \\ ${ }^{1,2,3}$ Jurusan Akuntansi, Fakultas Ekonomi dan Bisnis, Universitas Sam Ratulangi, Jl. Kampus Unsrat Bahu, \\ Manado, 95115, Indonesia \\ Email : ningsihkatili22@gmail.com
}

\begin{abstract}
ABSTRACK
Every organization requires an information system to facilitate the activities that have been planned and supervised to control the financial cash flow of the company, The purpose of this study was to know how the accounting information system of cash receipts in the department of PT. Ciputra International Manado branch, by tracking network accounting procedures that make up the system of cash receipts. The method used descriptive analysis method which research began by collecting and filtering the entire incoming information thoroughly and detail later elaborated in order to obtain a clear picture. The results showed that the accounting information system of cash receipts at the hospital department of PT. Ciputra International Manado branch is adequate because they were appropriate and meets the essential elements of an accounting information system that is human resources, equipment, forms or documents, records, procedures and reports. cash receipts and disbursements procedures have been arranged and done his best to avoid distortions that might occur, so that to date accounting information system cash receipts and disbursements in the department of PT. Ciputra International Manado branch can be done effectively. The solution is management, should implement every part to running the task as the authority.
\end{abstract}

Keywords: accounting information systems, cash receipts

\section{PENDAHULUAN}

Berkembangnya suatu usaha dari tingkat sederhana ke tingkat yang lebih luas dan maju tidak lepas dari kualitas kerja perusahaan. Kualitas laporan keuangan yang baik tidak mungkin dapat terwujud tanpa sistem penjagaan dan pengawasan serta prosedur kerja yang memadai. Dalam perkembangan dunia usaha sendiri, diperlukan sikap profesionalis dari setiap elemen yang ada dalam perusahan serta suatu control agar semua kegiatan berjalan sebagaimana mestinya. Hal ini sangat penting agar perusahaan dapat menjaga kelangsungan hidupnya. Sikap professional tersebut dapat tercermin dari kemampuan perusahaan untuk bersaing dipasar, yaitu strategi dimana perusahaan dapat memanfaatkan semua peluang dan kekuatan yang ada dan mampu menutup kelemahan serta menetralisir hambatan, strategi dalam dinamika bisnis yang dihadapi. Semua itu bisa dilakukan apabila manajemen mampu mengambil keputusan yang didasarkan pada masukan objektif.

Krismiaji (2015:4) Sistem Informasi Akuntansi adalah sebuah sistem yang memproses data dan transaksi guna menghasilkan informasi yang bermanfaat untuk merencanakan, pengendalian, dan mengoperasikan bisnis. Dalam sistem informasi akuntansi pengwasan intren membantu mendeteksi dan mencega pengaruh lingkungan terhadap sistem. Dalam pengambilan keputusan banyak faktor yang menjadi masukan manajer, salah satunya aspek yang paling penting dalam sistem informasi akuntansi adalah sistem tersebut berjalan dalam sruktur pengendalian intern perusahaan. Penegendalian serta pengelolaan manajemen dengan kebijakan dan pengarahan manajemen yang baik dan cukup memadai sehingga kegiatan perusahaan dapat berjalan sebagaimana mestinya. Pengelolaan keuangan dalam perusahaan 
merupakan kunci utama kegiatan operasional perusahaan dan tidak akan terlepas dari kegiatan yang berhubungan dengan kas.

Dalam menjalankan kegiatan operasionalnya, salah satu sistem yang diharapkan dapat menunjang keberhasilan perusahaan adalah sistem pengendalian maupun pengawasan terhadap kas dan pembentukan serta pengelolaan kas. Sistem ini memerlukan perhatian khusus karena berkaitan dengan kemampuan perusahaan dalam mengelola kekayaan yang dimiliki. Kas merupakan jenis aktiva yang mempunyai risiko tinggi untuk dijadikan sasaran kecurangan, karena kas sendiri merupakan aktiva perusahaan yang paling liquid mudah digelapkan dan diselewengkan. Dalam hal-hal tertentu tidaklah praktis untuk menggunakan cek/giro bilyet sebagai alat pembayaran seperti untuk pembelian alat tulis kantor dan berbagai macam pembayaran lainnya yang jumlahnya relatif kecil. Kuantitas transaksi ini relatif besar dan sifatnya segera. Perusahaan mengalokasikan sejumlah kas dalam jumlah tertentu yang disediakan untuk keperluan-keperluan pembayaran yang tidak mungkin dilakukan dengan menggunakan cek/Giro bilyet yang biasa disebut Kas Kecil. Pembentukan kas kecil adalah menyisihkan sejumlah dana untuk keperluan khusus, dengan mentransfer atau memindahbukukan sejumlah dana dari rekening kas yang ada di bank.

\section{TINJAUAN PUSTAKA}

\subsection{Pengertian Kas}

Kata kas atau cash memiliki berbagai pengertian, antara lain:

1. Kas berarti tempat menyimpan uang

2. Kas berarti uang (uang tunai)

3. Kas berarti tempat membayar dan menerima uang

4. Dalam kamus Istilah Akuntansi dijelaskan bahwa uang kas adalah setiap alat tukar yang diterima oleh bank dengan nilai nominal untuk disimpan. Uang kas suatu perusahaan terdiri dari uang kertas, uang logam, cek, wesel pos, dan uang yang disimpan di bank (demand deposit; simpanan deposito, yang sewaktu-waktu dapat dicairkan)

Dalam skripsi ini, yang dimaksud dengan kas adalah alat pembayaran tunai yang setiap saat dapat digunakan untuk membiayai berbagai macam kegiatan yang dilakukan oleh suatu lembaga, instansi, atau suatu perusahaan. Kas merupakan harta atau aktiva. Berbagai macam transaksi yang terjadi di suatu perusahaan merupakan penerimaan dan pengeluaran kas. Agar pengeluaran dan penerimaan kas tersebut dapat dengan mudah dikelolah, maka harus dicatat dalam suatu buku yang disebut buku kas.

\subsection{Sistem Akuntansi Kas}

Kas adalah harta lancar serta merupakan alat pertukaran atau alat pengukur dalam dunia usaha dan dunia perekonomian. Dalam neraca, kas merupakan aktivitas yang paling tinggi tingkat likuiditasnya, yaitu paling sering mengalami mutasi. Dalam kehidupan sehari - hari uang kas merupakan untuk media pertukaran secara umum. Kas menurut pengertian akuntansi adalah alat pertukaran yang dapat diterima untuk pelunasan utang dan dapat diterima sebagai suatu setoran ke bank dengan jumlah sebesar nominalnya, juga simpanan dalam bank atau tempat-tempat lainnya yang dapat diambil sewaktu-waktu. Pengertian lain dari segi akuntansi, yang dimaksud dengan kas adalah sesuatu (baik yang berbentuk uang atau bukan) yang dapat tersedia dengan segera dan diterima sebagai alat pelunasan kewajiban pada nilai nominalnya. Berdasarkan pengertian kas di atas, dapat disimpulkan bahwa kas merupakan sesuatu yang dapat diterima sebagai alat pelunasan kewajiban pada nilai nominalnya. Sistem Kas terbagi menjadi 2 sistem, yaitu :

1. Sistem Akuntansi Penerimaan Kas

2. Sistem Akuntansi Pengeluaran Kas 


\subsection{Sistem Akuntansi Penerimaan Kas}

Sistem akuntansi penerimaan kas adalah suatu catatan yang dibuat untuk melaksanakan kegiatan penerimaan uang dari penjualan tunai atau dari piutang yang siap dan bebas digunakan untuk kegiatan umum perusahaan. Beberapa definisi sistem akuntansi penerimaan kas menurut para ahli, diantaranya sebagai berikut :

Menurut Sujarweni (2015: 96) "Sistem penerimaan kas adalah suatu prosedur catatan yang dibuat untuk melaksanakan kegiatan penerimaan uang yang berasal dari berbagai macam sumber yaitu dari penjualan tunai, penjualan aktiva tetap, pinjaman dan setoran modal baru." Menurut Mulyadi (2016: 379), Penerimaan kas adalah kas yang diterima perusahaan baik yang berupa uang tunai maupun surat-surat berharga yang mempunyai sifat dapat segera digunakan, yang berasal dari transaksi perusahaan maupun penjualan tunai, pelunasan piutang, atau transaksi lainnya yang dapat menambah kas perusahaan. Sumber penerimaan kas terbesar suatu perusahaan dagang berasal dari transaksi penjualan tunai.

\subsection{Sistem Akuntansi Pengeluaran Kas}

Sistem akuntansi pengeluaran kas adalah suatu proses, cara, perbuatan mengeluarkan alat pertukaran yang diterima untuk pelunasan utang dan dapat diterima sebagai suatu setoran ke bank dengan jumlah sebesar nominalnya, juga simpanan dalam bank atau tempat lainnya yang dapat diambil sewaktu -waktu. Mulyadi (2016: 425) "Sistem akuntansi pengeluaran kas adalah suatu catatan yang dibuat untuk melaksanakan kegiatan pengeluaran baik dengan cek maupun dengan uang tunai yang digunakan untuk kegiatan umum perusahaan. James A Hall (2009:201) : "Sistem akuntansi pengeluaran kas adalah memproses pembayaran kewajiban yang dihasilkan oleh sistem pembelian." Berdasarkan dari beberapa pengertian diatas dapat disimpulkan bahwa sistem akuntansi pengeluaran kas pada umumnya didefinisikan sebagai organisasi formulir, catatan dan laporan yang dibuuat untuk melaksanakan kegiatan pengeluaran baik dengan cek maupun dengan uang tunai untuk mempermudah setiap pembiayaan pengelolaan perusahaan. Sistem Akuntansi pokok yang digunakan untuk melaksanakan pengeluaran kas yaitu sistem akuntansi pengeluaran kas dengan cek dan sistem akuntansi pengeluaran kas dengan melalui dana kas kecil. Mulyadi (2016) Sistem Akuntansi Penerimaan dan pengeluaran Kas

1. Fungsi yang terkait

2. Dokumen yang di perlukan

3. Catatan akuntansi yang digunakan

4. Prosedur yang dilaksanakan

5. Unsur pengendalian intern

6. Bagan Alir dokumen

\section{METODE PENELITIAN}

\subsection{Jenis Penelitian}

Jenis penelitian yang digunakan penulis adalah penelitian deskriptif (descriptive research) yaitu suatu penelitian yang bertujuan untuk menjelaskan atau mendeskripsikan suatu peristiwa, keadaan, objek apakah orang, atau segala sesuatu yang terkait dengan variabel-variebel yang bisa dijelaskan baik menggunakan angka-angka maupun kata-kata ( Punaji 2010)

\subsection{Jenis Data}
a. Data Primer
yaitu data yang diperoleh dan dikumpulkan secara langsung dari objek yang di teliti.
b. Data Sekunder 
yaitu data yang diperoleh dengan cara mempelajari hal-hal yang berasal dari buku-buku atau document tertentu yang berkaitan dengan masalah yang di hadapi kertas karya ini.

\subsection{Tempat dan Waktu Penelitian}

Penelitian ini dilakukan pada PT. Ciputra Internasional cabang Manado dengan waktu penelitian bulan Mei 2017 - Juni 2017

\subsection{Objek Penelitian}

Penelitian ini dilakukan pada PT. Ciputra Internasional Cabang Manado dengan mengambil data laporan keuangan Kas pada periode 2015-2016

\subsection{Metode Pengumpulan Data}

\subsubsection{Sumber data}

Sumber data dalam penelitian ini, yaitu

1. Data Primer, yaitu data yang diperoleh langsung oleh penulis dari objek penelitian dengan cara wawancara, dan data yang diambil dari perusahaan seperti buku kas umum dan buku kas

2. Data Sekunder, yaitu data yang berasal dari sumber atau pengamatan lain. Contohnya: buku- buku literatur yang digunakan sebagai acuan, jurnal penelitian yang berkaitan dengan akuntansi kas

\subsubsection{Teknik Pengumpulan Data}

Teknik Pengumpualan Data:

(1) Observasi partisipatorik

Adalah metode pengumpulan data dengan cara mengamati dan melaksanakan langsung terhadap obyek yang diteliti.

(2) Interview

Interview (wawancara) adalah tehnik pengumpulan data dengan cara mengajukan pertanyaan langsung kepada informan untuk memperoleh informasi yang diharapkan.

(3) Dokumentasi

dokumen merupakan catatan peristiwa yang sudah berlalu. Dokumen bisa

\subsubsection{Metode Analisis Data}

berbentuk tulisan, gambar, atau karya-karya monumental dari seorang.

Untuk menjawab rumusan masalah maka metode analisis yang digunakan adalah metode analisis deskriptif. Dengan metode analisis deskriptif, data yang diperoleh dianalisis secara umum tentang efektifitas penerapan sistem akuntansi penerimaan dan pengeluraan kas pada PT Ciputra Internasional, yaitu dengan mengkaji,memaparkan,menelaah, dan menjelaskan data-data yang diperoleh pada PT.Ciputra Internasional Cabang Manado untuk mendapatkan gambaran yang jelas dan menyeluruh tentang penerapan system pengendalian intern terhadap penerimaan dan pengeluraan kas.

\subsubsection{Teknik Analisis Data}

1. Mengumpulkan data yang berhubungan dengan penerimaan dan pengeluaran kas

2. Membandingkan teori dengan hasil penelitian

3. Membuat bagan alir dokumen (flowchart) sistem akutansi penerimaan dan pengeluaran kas

4. Membuat kesimpulan akhir yang menjadi bahan acuan bagi perusahaan dan sebagai informasi tambahan bagi PT. Ciputra Internasional 


\section{HASIL ANALISIS DAN PEMBAHASAN}

\subsection{Hasil Analisis}

\subsubsection{Jurnal Penerimaan Kas}

Dalam mencatat transaksi penerimaan kas PT. Ciputra Internasional Manado menggunakan laporan kas excel dan data yang sudah di masukkan ke dalam program Erems dapat ditarik laporannya untuk di rekonsel dengan data manualnya.

Contoh kasus :

Pada tanggal 22 Agustus 2015 terjadi transaksi penjualan Rumah di Block MP 02 maka pencatatannya yaitu :

Kas

XXX

Penjualan Rumah $\quad$ xxx

Pada tanggal 5 Oktober 2015 terjadi transaksi pembayaran Retribusi Air dari Block DH 07 maka pencatatanya yaitu :

Kas

$\mathrm{XXX}$

Retribusi Air

XXX

\subsection{Jurnal Pengeluaran Kas}

Catatan akuntansi yang digunakan dalam pengeluaran kas pada PT. Ciputra Internasional Manado adalah Buku Kas. Catatan ini digunakan untuk mencatat seluruh transaksi yang melalui kas. Proses pencatatannya dengan menggunakan sistem komputerisasi. Contoh Kasus :

Pada tanggal 15 mei 2017 pengeluaran dana untuk pendanaan yang diajukan oleh pihak kontraktor

\section{Pendanaan Kontraktor}

Kas
$\mathrm{XXX}$

XXX

\subsection{Pembahasan}

\section{2.1 Penerimaan Kas}

Berdasarkan hasil penelitian kesesuaian sistem informasi akuntansi penerimaan kas PT. Ciputra Internasional Cabang Manado secara garis besar dinyatakan telah sesuai berdasarkan kajian teori. Hal ini karena sebagian besar kriteria berdasarkan fungsi, dokumen, catatan dan jaringan prosedur pada sistem penerimaan kas yang dijalankan PT. Ciputra Internasional Cabang Manado telah sesuai dengan kajian teori. Dengan demikian sistem informasi akuntansi penerimaan kas PT. Ciputra Internasional Cabang Manado dianggap masih aman dan terhindar dari bahaya tindakan kecurangan yang mungkin dilakukan pihak internal maupun eksternal.

Pengendalian internal sangat penting untuk menjaga aktivitas sistem informasi akuntansi penerimaan kas, terdapat beberapa komponen pengendalian internal agar sistem informasi akuntansi dapat berjalan lebi terkoordinasi dan efektif tanpa adanya kecurangan. Berdasarkan penelitian mengenai kesesuaian prosedur pengendalian internal penerimaan kas dari penjualan tunai berdasarkan kajian teori ditemukan bukti bahwa seluruh komponen telah berjalan sesuai dengan teori walaupun tidak sepenuhnya dilaksanakan sama seperti pada teori. komponen dalam program sistem yang dijalankann untuk melakukan pencatatan transaksi secara terkomputerisasi tidak mengalami perubahan dari tahun sebelumnya. Pada komponen prosedur penggunaan dokumen dan catatan telah sesuai dengan aktivitas pengendalian internal penerimaan kas berdasarkan kajian teori. Dan untuk komponen pengecekan kinerja yang independen pada aktivitas pengendalian internal penerimaan kas juga tidak ditemukan perbedaan berdasarkan kajian teori. Dengan mempertimbangkan komponen lain yang sesuai berdasarkan teori dan tidak adanya kecurangan yang terjadi selama pengendalian internal atas seluruh aktivitas penerimaan kas. Maka dapat disimpulkan 
bahwa secara keseluruhan praktik yang diterapkan di PT Ciputra Internasional Cabang Manado sudah susuai dengan teori

\section{2. 2 Pengeluaran Kas}

Berdasarkan hasil penelitian kesesuaian sistem informasi akuntansi pengeluaraan kas PT. Ciputra Internasional Cabang Manado secara garis besar dinyatakan telah sesuai berdasarkan kajian teori. Hal ini karena sebagian besar kriteria berdasarkan fungsi, dokumen, catatan dan jaringan prosedur pada sistem pengeluaraan kas yang dijalankan PT. Ciputra Internasional Cabang Manado telah sesuai dengan kajian teori. Dengan demikian sistem informasi akuntansi pengeluaran kas PT. Ciputra Internasional Cabang Manado dianggap masih aman dan terhindar dari bahaya tindakan kecurangan yang mungkin dilakukan pihak internal maupun eksternal.

Pengendalian internal sangat penting untuk menjaga aktivitas sistem informasi akuntansi pengeluaraan kas, terdapat beberapa komponen pengendalian internal agar sistem informasi akuntansi dapat berjalan lebih terkoordinasi dan efektif tanpa adanya kecurangan. Berdasarkan penelitian mengenai kesesuaian prosedur pengendalian internal pengeluaran kas dengan cek berdasarkan kajian teori ditemukan bukti bahwa seluruh komponen telah berjalan sesuai dengan teori walaupun tidak sepenuhnya dilaksanakan sama seperti pada teori. komponen dalam program sistem yang dijalankann untuk melakukan pencatatan transaksi secara terkomputerisasi tidak mengalami perubahan dari tahun sebelumnya. Pada komponen prosedur penggunaan dokumen dan catatan telah sesuai dengan aktivitas pengendalian internal pengeluaran kas berdasarkan kajian teori. Dan untuk komponen pengecekan kinerja yang independen pada aktivitas pengendalian internal pengeluaran kas juga tidak ditemukan perbedaan berdasarkan kajian teori. Dengan mempertimbangkan komponen lain yang sesuai berdasarkan teori dan tidak adanya kecurangan yang terjadi selama pengendalian internal atas seluruh aktivitas pengeluaran kas. Maka dapat disimpulkan bahwa secara keseluruhan praktik yang diterapkan di PT Ciputra Internasional Cabang Manado sudah susuai dengan teori

\section{KESIMPULAN DAN SARAN}

\subsection{Kesimpulan}

Dari hasil penelitian yang telah dilaksanakan, semuanya telah diolah dan dibahas serta dirangkum lalu dibandingkan sebagaimana pada pembahasaan sebelumnya yaitu berdasarkan unsur-unsur sistem informasi akuntansi yang berlaku, sehingga evaluasi terhadap efektivitas penerapan sistem informasi akuntansi penerimaan dan pengeluaran kas pada PT.Ciputra Internasional Cabang Manado dapat disimpulkan bahwa Penerapan sistem Akuntansi Penerimaan dan Pengeluaran Kas PT.Ciputra Internasional Cabang Manado "Cukup efektif". Dikatakan cukup efektif karena masi terdapat beberapa hal yang menjadi bagian dari Sistem Informasi Akuntansi yang belum diterapkan

\section{2 Saran}

Dari hasil penelitian yang ada, penerapan Sistem Informasi Akuntansi terhadap Penerimaan dan Pengeluaran Kas dapat lebih efektif jika:

1. Dalam mengikuti perkembangan teknologi yang telah dikembangkan guna meningkatkan atau mempermudah proses pencatataan akuntansi perlu diadakan penyesuai terhadap perkembangan teknologi dengan memperbaharui program yang digunakan dalam pencatatan yaitu Microsoft Office

2. Untuk mempermuda konsumen dalam proses pembayaran perlu diterapkan proses pembayaran menggunakan kartu kredit yang telah mendapat persetujuan dari bank penerbit kartu kredit.

3. Adanya peningkatan jenjang pendidikan untuk pihak yang menangani proses pelaporan penerimaan dan pengeluaraan kas sehingga dalam menangani masalah pelaporan yang 
ada pihak yang sudah memiliki kemampuan untuk menangani masalah yang berkaitan dengan proses pelaporaan keuangan kususnya dibagian akuntansi yang seharusnya menggunakan sumber daya yang memiliki pendidikan yang sesuai dibidangnya yaitu profesi akuntan

\section{DAFTAR PUSTAKA}

Andrew Marco Saputra (2013) Analisis Penerapan Sistem dan Prosedur Pengeluaran Kas pada BPBD Sulawesi Utara

Dunia Firdaus (2009), Pengantar Akuntansi I, FE Universitas Indonesia, Jakarta.

Harahap Sofyan Syahri (2013), Teori Akuntansi, Edisi Revisi, PT. Grafindo Persada, Jakarta.

Harnanto (2013), Akuntansi Keuangan Menengah, Liberty, Yogyakarta.

Krismiaji (2015 ) Sistem Informasi Akuntansi, Edisi 4 , UPP STIM YKPN

Mario Caesar Piet Sumurung (2015) Analisis Pengendalian Penerimaan dan Pengeluaran Kas pada PT. Manado Media Grafika

Mulyadi (2016), Sistem Akuntansi, Edisi 4, Salemba Empat.

Merystika Kabuhung (2013) Sistem Informasi Akuntansi Penerimaan dan Pengeluaran Kas untuk Perencanaan dan Pengendalian Keuangan pada Organisasi Nirlaba Keagamaan Skripsi, E-Library Fakultas Ekonomi dan bisnis Univesitas samrat tulanggi Manado.

Patricia Mamahit (2014) Evaluasi Sistem Informasi Akuntansi Penerimaan dan Pengeluaran Kas Rawat Inap pada RSUP. Prof. R D. Kandou Manado,Skripsi, E-Library Fakultas Ekonomi dan bisnis Univesitas samrat tulanggi Manado

Rahmad Mahmud (2016) Analisis Sistem dan Prosedur Pengeluaran Kas dengan menggunakan Uang Persediaan (UP) pada Dinas Sosial Kota Manado, Skripsi, ELibrary Fakultas Ekonomi dan bisnis Univesitas samrat tulanggi Manado

Rannita M. Manoppo (2013) Analisis Sistem Pengendalian Intern Penerimaan dan Pengeluaran Kas pada PT. Sinar Galesong Prima Cabang Manado Skripsi, ELibrary Fakultas Ekonomi dan bisnis Univesitas samrat tulanggi Manado 